\title{
IMPLEMENTATION OF PROJECT-BASED LEARNING THROUGH STEM APPROACH TO IMPROVE STUDENTS' SCIENCE PROCESS SKILLS AND LEARNING OUTCOMES
}

\author{
Helvy Aprianty ${ }^{1}$, Abdul Gani ${ }^{2 *}$ and Andi Ulfa Tenri Pada ${ }^{3}$ \\ ${ }^{1}$ Department of Science Education, Graduate Program, Universitas Syiah Kuala, \\ Jl. Tgk. Chik Pante Kulu No. 5, Banda Aceh, 23111, Indonesia \\ ${ }^{2}$ Department of Chemistry Education, Faculty of Teacher Training and Education, \\ Universitas Syiah Kuala, Jl. Tgk. Hasan Krueng Kalee, Banda Aceh, 23111, Indonesia \\ ${ }^{3}$ Department of Biology Education, Faculty of Teacher Training and Education, Universitas \\ Syiah Kuala, Jl. Tgk. Hasan Krueng Kalee, Banda Aceh, 23111, Indonesia \\ “E-mail: abdulgani051266@gmail.com
}

Received: 07 September 2020; Accepted: 24 November 2020; Published: 31 December 2020

\begin{abstract}
This study aimed to determine PjBL-STEM implementations effect to improve science process skills and students' learning outcomes on the material of substances and their characteristics. The type of research used was a quasi-experiment with a pre-test post-test control group design. The research subjects were students of class VII Darul Ihsan Islamic Junior High School Aceh Besar, which consisted of eight classes. The sample group was determined by purposive sampling technique so that two classes were obtained as the research sample, namely class VII-G as an experimental class and VII-H as a control class. The results showed that the implementation of the PjBL-STEM model could increase students' science process skills. The average students' science process skills in the control and experimental classes were 53 and 55 with sufficient categories. However, after implementing the Discovery Learning model in the control class and PjBL-STEM in the experimental class, the students' science process skills' average score increased to 76 with good categories and 86 with excellent categories. The PjBL-STEM model was also able to improve students' learning outcomes. Based on the results of the t-test analysis with a significant score of 0.05 , it showed that the post-test scores in both classes were obtained $t$-count $(2.011)>t$-table (1.666), so it was concluded that there was a significant difference between the two classes. $\mathrm{N}$-gain testing showed an increase in students' learning outcomes between the control and experimental classes with scores of 74 and 79. This study concluded that the PjBL-STEM model could improve science process skills and students' learning outcomes.
\end{abstract}

Keywords: learning outcomes, PjBL-STEM model, science process

DOI : https://doi.org/10.15575/jtk.v5i2.8370

\section{INTRODUCTION}

The results of science learning in Aceh are currently low. This is evidenced from the National Science Examination data for the last 4 years from the 2015/2016, 2016/2017, $2017 / 2018$ to $2018 / 2019$ academic year with respective scores of $56.33,40.47,38.75$ and
38.43. Especially the National Examination score for the 2018/2019 academic year on substances material and their characteristics, which is one of the science learning materials, with an average value of 36.72. This achievement is low compared to the national score of around 47.47 (Puspendik, 2019).

Based on the results of interview that was conducted with one of the science subject 
Implementation of Project-Based Learning through STEM Approach to Improve Students' Science Process Skills and Learning Outcomes

teachers at Darul Ihsan Islamic Junior High School, it was found that the KKM (Kriteria Ketuntasan Minimum/ Minimum Completeness Criteria) score for science subject at the school is 65 . While the average score for the students' daily tests was 42.5. The completeness level of students' daily tests based on minimum completeness criteria was around $45 \%$ and that still low, so it can be concluded that the students' learning outcomes in science learning are still not optimal. This is supported by the results of observations that there were still many students memorizing the science learning concept without understanding it. The results also show that the use of facilities and infrastructure that support the teaching and learning process such as projectors was still not optimal. The absence of a laboratory also has an impact on the lack of practical implementation in the school. Thus it will impact on low students' science process skills (Wardani et al., 2017).

Science process skill is a skill that starts from observing, measuring, classifying, concluding and communicating (A'yun \& Subali, 2018). One of the science learning materials that requires the implementation of science process skills in the learning process is substances and their characteristics. It is hoped that students can design an activity that is able to add new knowledge from the observation and experiment process. This can be achieved if there are efforts that can support the students' performance, one of them with combining the Project-Based Learning ( $\mathrm{PjBL})$ model with the Science, Technology, Engineering and Mathematics (STEM) approach or known as PjBL-STEM. Hariyanto et al. (2019) suggested that the PjBL model and the STEM approach are a combination that is very suitable to be applied in the 2013 curriculum learning, due to the similarities between them which are able to provide meaningful learning experiences for students.

$\mathrm{PjBL}$ is a learning model that uses projects as learning media (Darmadi 2017). PjBL model can improve students' science process skills
(Asmi et al., 2017). Sumarni et al. (2016) stated that PjBL helps students develop psychomotor skills and understanding concepts. PjBL is also able to foster students' creativity and motivation to learn (Kuo et al., 2019). Fauzan et al. (2017) stated that PjBL model can improve students' learning outcomes. The implementation of $\mathrm{PjBL}$ in science learning can be combined with the STEM approach (Permanasari, 2017).

STEM is an interdisciplinary approach that can help students understand in depth any material related to science, technology, engineering and mathematics (Fatmawati et al., 2015). STEM can make students more actively involved in learning and develop an understanding of material concepts with their benefits in everyday life (Dasgupta et al., 2019). Safitri et al. (2018) and Amatullah et al. (2019) stated that STEM can improve students' learning outcomes. Learning using this approach will be more fun so that it will affect students' learning interest (Barry et al., 2019).

PjBL and STEM are suitable to be combined because the focus of both learning lies in the products that students produce (Yulia et al., 2019). The PjBL model combined with STEM can increase scientific literacy, motivation and interest in learning (Afriana et al., 2016). Another success mentioned by Afifah et al. (2019) that the use of PjBL-STEM can develop mastery of concepts and critical thinking skills. This is also in accordance with the statement of Saleh et al. (2020) and Beier et al. (2018) that PjBL-STEM can improve conceptual understanding and make students more actively involved in learning.

\section{RESEARCH METHOD}

The type of research used was quasiexperimental with a quantitative approach. The research design used was pre-test-posttest control group design. The population in this study were all students of class VII at Darul Ihsan Islamic Junior High School Aceh Besar in the 2019/2020 academic year, which consisted of 8 classes with a total of 256 students. Sampling was carried out by purposive 
Implementation of Project-Based Learning through STEM Approach to Improve Students' Science Process Skills and Learning Outcomes

sampling technique with the sample requirements based on the same natural sciences value characteristics to determine the control and experimental classes. Based on the sampling technique, it was obtained class VII$G$ with 36 students as the experimental class and class VII-H with 38 students as the control class. Data collection was obtained through science process skills validation sheets and test questions. The data were analyzed using the questions' difficulty level test, the validity test, the reliability test, the $\mathrm{N}$-gain, and the $\mathrm{t}$ test to determine science process skills and students' learning outcomes. The data were also analyzed using the discrimination index, which intends to measure to what extent the question distinguishes the students (Azevedo et al., 2019).

The implementation of the PjBL-STEM model was used in the experimental class, with several stages including reflection, research, discovery, application and communication. Whereas in the control class, a conventional model in the form of Discovery Learning (DL) was used with the syntax starting from providing stimulation, identifying problems, collecting and processing data, proving and drawing conclusions.

\section{RESULT AND DISCUSSION}

\subsection{Students' Science Process Skills Data Analysis}

The instrument for measuring the students' science process skills in this study was an observation sheet developed by Subali (2009). The students' science process skills assessment was carried out twice for each class. The analysis of science process skills improvement can be seen from the percentage of each science process skills aspect which includes basic, processing and investigating skills.

The analysis of students' science process skills improvement was obtained using the t-test and $\mathrm{N}$-gain. The students' science process skills acquisition score in this study was seen before and after the implementation of the PjBL-STEM model which aims to find out the improvements that have occurred during the learning process both in the control and experimental classes. The average science process skills score before being given treatment in the control and experimental classes was 53 and 55, both of which belong to the sufficient category. Overall, the two data are not significantly different so it can be assumed that the initial science process skills abilities of students in the control and experimental classes are same. After knowing the students' initial science process skills score, the two classes were given treatment by implemented the DL model in the control class and PjBL-STEM in the experimental class.

Science process skills assessment in the control class was conducted in four meetings. At the first and second meetings, the aspect assessed was basic skills with the sub-aspects of observing and recording the data or information provided. At the third meeting, the aspect assessed was processing skill in the form of making predictions. At the fourth meeting, the aspects assessed were related to several aspects of basic, processing and investigating skills. Sub-aspects of basic skills included following orders, taking measurements, manipulating movements, implementing procedures and techniques. Sub-aspects of processing skills included differentiating and selecting procedures. Furthermore, the last aspect assessed was investigating skills which are based on designing, implementing, and reporting research results. In the control class, the average score of science process skills for each aspect showed an increase. The average percentage of science process skills in the control class through the implementation of the DL model showed an increase from 53 (sufficient category) to 76 (good category).

Science process skills assessment in the experimental class was also conducted in four meetings. At the first meeting, the aspect assessed was basic skills with the sub-aspects of observing and recording the data or information provided. Science process skills at the second meeting were assessed based on 2 aspects, basic skills with the sub-aspect of movement manipulation activities and 
Implementation of Project-Based Learning through STEM Approach to Improve Students' Science Process Skills and Learning Outcomes

investigating skills with the sub-aspect of designing research. At the third meeting, the aspect assessed was basic skills with the subaspects of following orders and taking measurements. The second aspect assessed in this third meeting learning process was processing skills with the sub-aspect of making predictions. At the last meeting, the aspect assessed was processing skills with the sub-aspect of differentiating activities. Furthermore, the last aspect assessed was investigating skills including the activities of carrying out and reporting research results. The results of the assessment showed that the average score in the experimental class using the PjBL-STEM model has increased from 55 (sufficient category) to 86 (very good category). The average score before and after the implementation of DL and PjBL-STEM models can be seen in Figure 1.

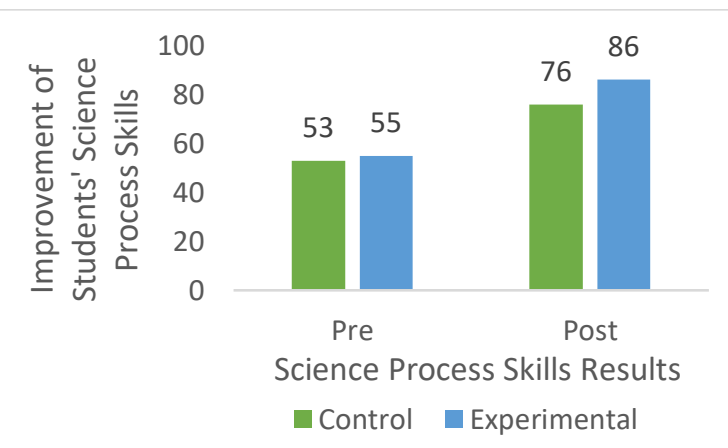

Figure 1. Improvement of Students' Science Process Skills

Figure 1 shows that the increase in science process skills after implementing the DL and PjBL-STEM models occured in both classes, but the increase in the experimental class is higher than in the control class. This results are supported by the research of Anggraini et al. (2019) which states that PjBL can increase students' science process skills by $19,36 \%$. This can happen because one of the advantages of PjBL model implementation is that it can make students actively involved in all learning activities presented by the teacher and can help solve problems related to real life. In addition, this model can also increase teamwork so that it will affect students' science process skills (Astutik et al., 2019).

\subsubsection{Students' Science Process Skills T- Test}

Hypothesis testing related to the science process skills improvement was analyzed using the t-test with a significance value of 0.05 . The test results show the final science process skills scores of students in both classes has sig. (2-tailed) with a value of 0.048 . This can be concluded that there are significant differences between the two classes. This difference can be an increase in the science process skills that occurred in the experimental and control classes. $\mathrm{N}$-gain test was used to determine whether an increase has occurred or not.

\subsubsection{Students' Science Process Skills Improvement}

The assessment of science process skills in this study was also determined using $\mathrm{N}$-gain which aims to see the improvement that occured in the control and experimental classes. The average score for the science process skills aspect can be seen in Figure 2.

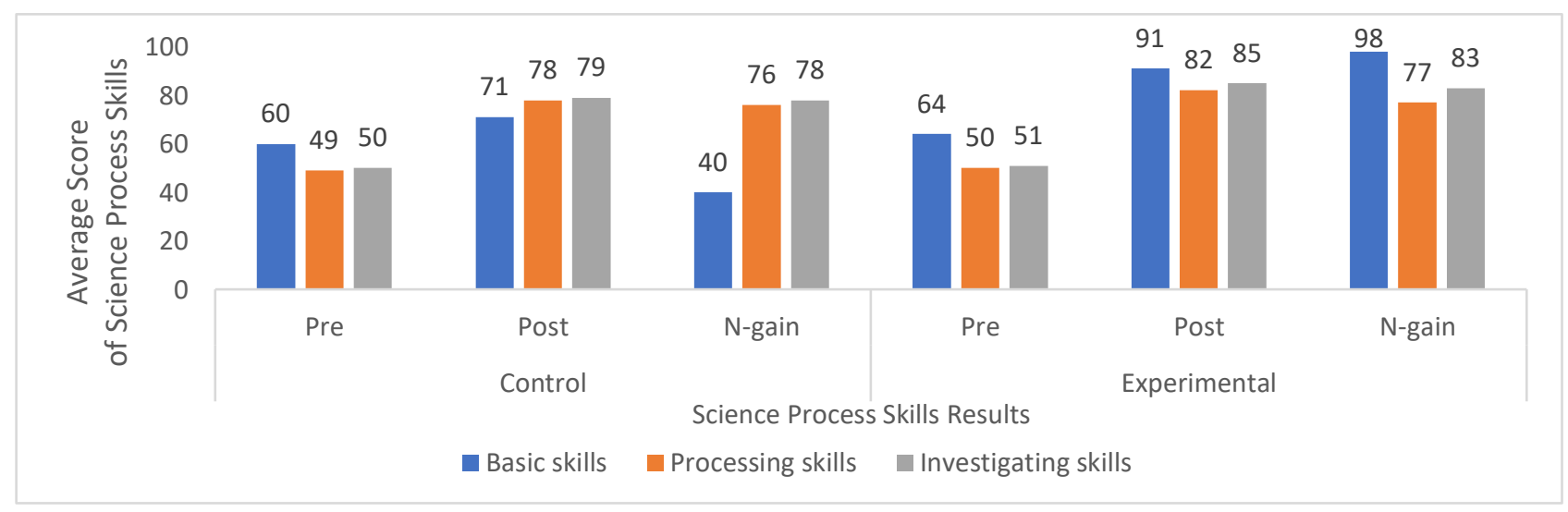

Figure 2. The Average Score of Science Process Skills Aspect

This is an open access article under CC-BY-SA license (https://creativecommons.org/licenses/by-sa/4.0/) 
Implementation of Project-Based Learning through STEM Approach to Improve Students' Science Process Skills and Learning Outcomes

As shown in Figure 2, students' science process skills increase in both the control and experimental classes. However, the increase in the experimental class is higher than the control class. The increase in science process skills that occurred in the experimental class was due to the implementation of model and the use of PjBL-STEM-based student worksheets in the learning process. This is because PjBL-STEM-based student worksheets can direct students to be actively involved, can improve performance in practicing, increase scientific literacy, and develop an understanding of knowledge and mathematics concept, and its application in real life contexts. Triana et al. (2020) stated that combining PjBL and STEM will be a learning support that capable of improving the students' skills. Nadelson and Seifert (2017) stated that the use of STEM in the learning process has a very big impact, one of which is being able to increase the involvement of students in the learning process. Stohlmann et al. (2012) added to the success of using STEM in teaching and learning activities by saying that this approach is also able to help students understand the scientific process, problem solving techniques and the application of technology.

\subsection{Students' Learning Outcomes Resullts Data Analysis}

Assessment of students' learning outcomes on substance material and its characteristics in this study were obtained from pre-test and post-test values which aim to determine the increase in student learning outcomes between the control and experimental classes at Darul Ihsan Islamic Junior High School Aceh Besar. The pre-test and post-test scores can be obtained after students answer the questions, which amount to 20 items. Before being given to students, the questions were validated first by two experts. Pada (2014) stated that the validation function in research activities is to draw scientific conclusions about the relationship between variables and as a support for the test to be used. The giving of pre-test questions in both classes was carried out at the first meeting before implementing the learning model. Post-test questions were given to both classes after the implementation of the PjBL-STEM model in the experimental class and DL model in the control class. The results obtained were then tested using the normality test, homogeneity and hypothesis testing (t-test) to see the increase.

Learning outcomes can be seen from the acquisition of pre-test and post-test scores that have been given to students. The students' pre-test score in the control and experimental classes was 40.5 and 44.67. This result shows that the pre-test average score for both the control and experimental classes is still low. This explains that the knowledge of students on substance materials and their characteristics is still low. The post-test was carried out at the last meeting to see how much increase in students' knowledge after the teaching and learning process. The average post-test percentage of the control and experimental classes is 80 and 84 . Based on this score, the knowledge of students in both classes increased, but the experimental class has a higher increase than the control class.

This proved that learning process using PjBLSTEM model can make student learning outcomes better. This statement is in accordance with Astuti et al. (2019) which stated that the PjBL-STEM model can improve students' mastery of concepts which will have an impact on learning outcomes. Sumardiana et al. (2019) stated that learning by utilizing the STEM-based PjBL model can help students gain new knowledge that can be used to solve various kinds of problems in real life. Learning by utilizing the PjBL model can make students better understand the material being taught. This is due to the assignments to find and explore their own solutions to the problems given then discuss them together in class (Anita, 2017). The use of PjBL in the learning process according to Sitaresmi et al. (2017) can also improve students' learning practices.

\subsubsection{Students' Learning Outcomes T-Test} Based on the normality and homogeneity test, it is known that the students' learning outcomes data are normally distributed and homogeneous, so that the t-test can be done to see whether the hypothesis is accepted or

This is an open access article under CC-BY-SA license (https://creativecommons.org/licenses/by-sa/4.0/) 
Implementation of Project-Based Learning through STEM Approach to Improve Students' Science Process Skills and Learning Outcomes

rejected. The t-test was measured using an independent sample test through SPSS version 20 software with a significant value of 0.05 . The test results showed that the post-test scores in the control and experimental classes obtained $t$-count (2.011) $>\mathrm{t}$-table (1.666), it can be concluded that there is a significant difference between the two classes. This difference can be seen in the class that was treated using the PJBL-STEM model which had a higher score.

\subsubsection{Students' Learning Outcomes Improvement}

Assessment of learning outcomes was measured using the $\mathrm{N}$-gain which aims aims to see the improvement that occured in the control and experimental classes. Complete data regarding the $\mathrm{N}$-gain test can be seen in Figure 3.

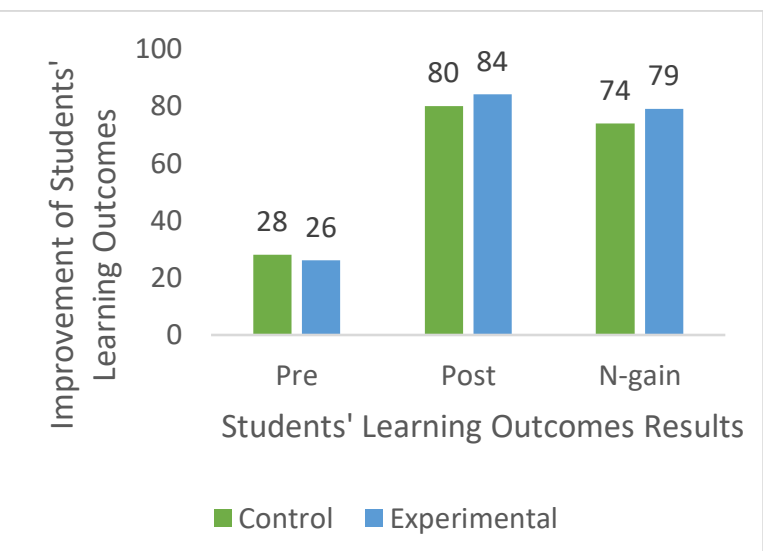

Figure 3. Improvement of Students' Learning

Figure 3 shows that in general there is an increase in students' learning outcomes in the control and experimental classes. The improvement that occurred in the two classes did not have a significant difference. The PjBLSTEM model did not provide a significant difference, because the increase in learning outcomes that occurred in the experimental class was not much different from the control class that applied the DL model. With the score acquisition of 80 in the control class and 84 in the experimental class, both scores have exceeded the the minimum completeness criteria set by Darul Ihsan Islamic Junior High School Aceh Besar. Based on observations made during the learning process, students in both classes seemed active and enthusiastic in following the learning process.

The students' learning outcomes improvement in the experimental class was due to an opportunity for students to develop their skills and knowledge when carrying out practical activities based on the PjBL-STEM student worksheets which given at the third meeting. The statement that supports the improvement of learning outcomes due to the application of this model was stated by Tipani et al. (2019) that PjBL-STEM can improve conceptual mastery of the material being taught and students' analytical abilities. Other opinions were also stated by Sumarni et al. (2019) by saying that PjBL-STEM can help students improve their cognitive abilities.

\section{CONCLUSION}

Based on the research that has been done, it can be concluded that there is an increase in students' science process skills and learning outcomes after implementing the PjBL learning model through the STEM approach. The average score of the students' science process skills increased from 55 to 86 for the experimental class and 53 to 76 for the control class. The average score of the students' learning outcomes increased from 26 to 84 for the experimental class and 28 to 80 for the control class. The test results showed that the post-test scores in the control and experimental classes obtained $t$-count (2.011) > $\mathrm{t}$-table (1.666), it can be concluded that there is a significant difference between the two classes. 
Implementation of Project-Based Learning through STEM Approach to Improve Students' Science Process Skills and Learning Outcomes

\section{REFERENCES}

Afifah, A. N., Ilmiyati, N., \& Toto, T. (2019). Model project based learning (PjBL) berbasis STEM untuk meningkatkan penguasaan konsep dan keterampilan berpikir kritis siswa. Quangga: Jurnal Pendidikan dan Biologi, 11(2), 73-78. https://doi.org/10.25134/quagga.v11i2. 1910

Afriana, K., Permanasari, \& Fitriani, A. (2016). Penerapan project based learning terintegrasi STEM untuk meningkatkan literasi sains siswa ditinjau dari gender. Jurnal Inovasi Pendidikan IPA, 2(2), 202212.

https://doi.org/10.21831/jipi.v2i2.8561

Amatullah, S. F., Distrik, I. W., \& Wahyudi, I. (2019). Pengaruh model pembelajaran inkuiri terbimbing berbantukan buku siswa berbasis pendekatan terpadu STEM terhadap hasil belajar. JPF (Jurnal Pendidikan Fisika), 7(1), 15-27. http://dx.doi.org/10.24127/jpf.v7i1.1341

Anggraini, F., Wijayati, N., Susatyo, E. B., \& Kharomah, K. (2019). Pengaruh Projectbased learning produk kimia terhadap pemahaman konsep dan keterampilan proses sains siswa SMA. Jurnal Inovasi Pendidikan Kimia, 13(2), 2404-2413. Retrieved from https://journal.unnes.ac.id/nju/index.ph p/JIPK/article/view/18548

Anita, I. W. (2017). Implementasi pembelajaran berbasis proyek untuk menumbuhkan kemampuan berpikir kreatif matematis mahasiswa. JPPM (Jurnal Penelitian dan Pembelajaran Matematika, 10(2), 125131.

http://dx.doi.org/10.30870/jppm.v10i1.1 287

Asmi, S., Hasan, M., \& Safitri, R. (2017). Penerapan model pembelajaran berbasis proyek pada materi suhu dan kalor untuk meningkatkan keterampilan proses. Jurnal Pendidikan Sains

This is an open access article under CC-BY-SA license (https://creativecommons.org/licenses/by-sa/4.0/) 
Implementation of Project-Based Learning through STEM Approach to Improve Students' Science Process Skills and Learning Outcomes

Science Teaching, 56(1), 3-23. https://doi.org/10.1002/tea.21465

Darmadi, H. (2017). Pengembangan Model dan Metode Pembelajaran dalam Dinamika Belajar Siswa. Yogyakarta: Deepublish.

Dasgupta, C., Magana, A. J., \& Vieira, C. (2019). Investigating the affordances of a CAD enabled learning environment for promoting integrated STEM learning. Computer \& Education, 129, 122-142. https://doi.org/10.1016/j.compedu.2018 .10 .014

Fatmawati, S., Ariesta, N., Susanti, L. Y., Darmaji, \& Putra, S. R. (2015). Desain laboratorium skala mini untuk pembelajaran sains terpadu. Yogyakarta: Deepublish.

Fauzan, M., Gani, A., \& Syukri, M. (2017). Penerapan model problem based learning pada pembelajaran materi sistem tata surya untuk meningkatkan hasil belajar siswa. Jurnal Pendidikan Sains Indonesia (Indonesian Journal of Science Education), 5(1), 27-35. Retrieved from http://jurnal.unsyiah.ac.id/JPSI/article/vi ew/8404

Hariyanto, H., Yamtinah, S., Saputro, S., \& Mahardiani, L. (2019). Penerapan model project based learning (PjBL) terintergrasi pendekatan STEM dalam meningkatkan pemahamahan konsep peserta didik di salah satu sekolah daerah Tangerang Selatan. Prosiding Seminar Nasional Pendidikan Sains 2019, 256-261, Surakarta: Magister Pendidikan Sains, Fakultas Keguruan dan Ilmu Pendidikan Universitas Sebelas Maret. Retrieved from http://jurnal.fkip.uns.ac.id/index.php/sn ps/article/view/12848

Kuo, H. C., Tseng, Y. C., \& Yang, Y. T. C. (2019). Promoting college student's learning motivation and creativity through a STEM interdisciplinary PBL human-

computer interaction system design and development course. Thingking Skills and Creativity, 31, 1-10. https://doi.org/10.1016/j.tsc.2018.09.00 1

Nadelson, L. S., \& Seifer, A. L. (2017). Integrated STEM defined: contexts, challenges, and the future. The Journal of Educational Research, 110(3), 221223.

https://doi.org/10.1080/00220671.2017. 1289775

Pada, A. U. T. (2014). Generalisasi validitas dalam penelitian kuantitatif. Biologi Edukasi: Jurnal Ilmiah Pendidikan Biologi, 6(1), 39-42. Retrieved from http://jurnal.unsyiah.ac.id/JBE/article/vie $w / 2275 / 2866$

Permanasari, A. (2017). STEM education: inovasi dalam pembelajaran sains dalam menapaki pendidikan abad 21. Prosiding Seminar Nasional Pendidikan IPA VIII, 11-29, Surabaya: Universitas Negeri Surabaya. Retrieved from http://sains.fmipa.unesa.ac.id/wpcontent/uploads/2017/09/ProsidingSeminar-Nasional-IPA-VIII-2017.pdf

Puspendik. (2019). Laporan Hasil Ujian Nasional SMP/MTs Tahun Pelajaran 2018/2019.

(http://puspendik.kemdikbud.go,id/hasi l-un), accessed 19 September 2019.

Safitri, E., Handayani, S., \& Mujdalipah, S. (2018). Pembelajaran praktikum dengan modul berbasis science, technology, engineering and mathematics (STEM) untuk meningkatkan hasil belajar siswa pada kompetensi dasar melakukan dasar pengawetan. Edufortech, 3(2), 93100.

https://doi.org/10.17509/edufortech.v3i 2.13584

Saleh, S., Muhammad, A., \& Abdullah, S. M. S. (2020). STEM project-based approach in enhancing conceptual understanding

\footnotetext{
This is an open access article under CC-BY-SA license (https://creativecommons.org/licenses/by-sa/4.0/)
} 
Implementation of Project-Based Learning through STEM Approach to Improve Students' Science Process Skills and Learning Outcomes

and inventive thinking skills among secondary school students. Jonus (Journal of Nusantara Studies), 5(1), 234254.

https://doi.org/10.24200/jonus.vol5iss1 pp234-254

Sitaresmi, K. S., Saputro, S., \& Utomo, S. B. (2017). Penerapan pembelajaran project based learning (PjBL) untuk meningkatkan aktivitas dan prestasi belajar siswa pada materi sistem periodik unsur (SPU) kelas X MIA 1 SMA Negeri 1 Teras Boyolali tahun pelajaran 2015/2016. Jurnal Pendidikan Kimia, 6(1), 54-61. Retrieved from http://jurnal.fkip.uns.ac.id/index.php/ki mia/article/view/9405

Stohlmann, M., Moore, T. J., \& Roehrig, G. H. (2012). Considerations for teaching integrated STEM education. Journal of Pre-College Engineering Education Reasearch (J-PEER), 2(1), 28-34. https://doi.org/10.5703/1288284314653

Subali, B. (2009). Pengembangan tes pengukur keterampilan proses sains pola divergen mata pelajaran biologi sains. Prosiding Seminar Nasional Biologi, Lingkungan dan Pembelajarannya, 581-598, Yogyakarta: Jurusan Pendidikan Biologi, Fakultas Matematika dan Ilmu Pengetahuan Alam Universitas Negeri Yogyakarta. Retrieved from http://staff.uny.ac.id/sites/default/files/ penelitian/Bambang\%20Subali,\%20Dr/s emnas\%20bio\%20_Bambang\%20Subali _UNY-2009.pdf

Sumardiana, S., Hidayat, A., \& Parno, P. (2019). Kemampuan berpikir kritis pada model project based learning disertai STEM siswa SMA pada suhu dan kalor. Jurnal Pendidikan: Teori, Penelitian, dan Pengembangan (Education Journal: Theory, Research, and Development), 4(7), 874-879. http://dx.doi.org/10.17977/jptpp.v4i7.1 2618
Sumarni, W., Wijayati, N., \& Supanti, S. (2019). Analisis kemampuan kognitif dan berpikir kreatif siswa melalui pembelajaran berbasis proyek berpendekatan STEM. J-PEK (Jurnal Pembelajaran Kimia), 4(1), 18-30. http://dx.doi.org/10.17977/um026v4i12 $019 \mathrm{p} 018$

Sumarni, W., Wardani, S., Sudarmin, \& Gupitasari, D. N. (2016). Project based learning (PjBL) to improve psychomotoric skills: a classroom action research. Jurnal Pendidikan IPA Indonesia (Indonesian Journal of Science Education), 5(2), 157-163. https://doi.org/10.15294/jpii.v5i2.4402

Tipani, A., Toto, T., \& Yulisma, L. (2019). Implementasi model PjBL berbasis STEM untuk meningkatkan penguasaan konsep dan kemampuan analitis siswa. Bio Educatio: The Journal of Science and Biology Education, 4(2), 70-76. http://dx.doi.org/10.31949/be.v4i2.1700

Triana, D., Anggraito, Y. U., \& Ridlo, S. (2020). Effectiveness of environmental change learning tools based on STEM-PjBL towards 4C skills of students. Journal of Innovative Science Education, 9(1), 181187.

https://doi.org/10.15294/jise.v8i3.34048

Wardani, Y. R. K, Fadiawati, N., \& Tania, L. (2017). Efektifitas pendekatan saintifik dalam meningkatkan keterampilan proses sains pada materi pemisahan campuran. Jurnal Pendidikan dan Pembelajaran Kimia, 6(1), 116-129. Retrieved from http://jurnal.fkip.unila.ac.id/index.php/J PK/article/view/13152

Yulia, Y., Zubainur, C. M., \& Johar, R. (2019). Keterlibatan perilaku siswa dalam pembelajaran matematika melalui STEMPjBL di SMPN 2 Banda Aceh. Jurnal Ilmiah Mahasiswa Pendidikan Matematika, 4(1), 29-37. Retrieved from http://jim.unsyiah.ac.id/pendidikanmatematika/article/view/9451 